\title{
'E sí la hoïren tots': sí and emphatic positive polarity in Old Catalan
}

\author{
Afra Pujol i Campeny \\ University of Cambridge \\ ap666@cam.ac.uk
}

Received: 20-08-2018

Accepted: 02-07-2019

\begin{abstract}
This paper explores the semantic value and syntactic distribution of the lexical item sí in Old Catalan. By examining data extracted from 13th century legal and historiographical texts, it is concluded that sí was an Emphatic Positive Polarity Particle (EPPA) whose appearance was restricted to non-veridical contexts, as well as a positive sentential proform, already by that date. This analysis strongly contrasts with analyses put forward for sí in Old Catalan and Old Spanish that date its grammaticalization as an EPPA two centuries later, and with analyses of sí in other Old Romance languages that have linked it to the satisfaction of the V2 parameter.
\end{abstract}

Keywords: Old Catalan; sí; positive polarity; grammaticalisation.

\section{Table of Contens}

1. Introduction

2. Emphatic Positive Polarity in Latin

3. Sí across the Old Romance

languages
4. Sí in Old Catalan

5. Summary of findings

References 


\section{Introduction}

In this article we explore the semantics and distribution of the particle sí in Old Catalan with data drawn from three $13^{\text {th }}$ century textual sources. It is shown that Old Catalan had already grammaticalised sí into a positive sentential proform by the $13^{\text {th }}$ century, even though its usage was strongly determined by register and stylistic factors. Furthermore, it is also shown that sís distribution was not limited to answer yes/no questions: it could also occur as an Emphatic Positive Polarity Particle in fully fledged clauses within the scope of a non-veridical operator.

While Latin did not have a positive sentential proform, several sentential proforms are found across the Romance languages: Old Catalan and Occitan grammaticalised the demonstrative HOC into $o c$ 'yes', now lost in Modern Catalan but still in use in Modern Occitan; in French; the demonstrative phrase HOC ILLUD was grammaticalised into oui 'yes', while the Latin manner adverb SIC was grammaticalised as sí 'yes' in Catalan, Spanish and Italian, and as sim in Portuguese.

The grammaticalisation of Latin SIC, a VP manner adverb, into the Emphatic Positive Polarity Particle (EPPA) sí that is found in Modern Catalan has been extensively studied by Batllori \& Hernanz (2008, 2013). According to these authors, in the Medieval period, sí, still and adverb, was merely used as a reinforcement of other strategies to convey positive polarity (Batllori and Hernanz 2008:14), while in the Modern language, after undergoing grammaticalisation, it acts as a positive sentential proform that is used in yes/no questions.

While I agree and endorse Batllori and Hernanz's $(2008,2013)$ analysis of the grammaticalisation of sí, the data presented in this paper suggests that the grammaticalisation of sí occurs earlier than previously thought and that its distribution was wider than previously described. Therefore, Old Catalan is the first Old Romance language in which sí is attested as a positive sentential proform. This is shown by examining three Old Catalan texts dating from the $13^{\text {th }}$ century: two historiographical chronicles and one compilation of legal texts (mainly containing complaints and reports): (i) El Llibre dels Fets, (1244-1274), henceforth ' $L d F$ ', (ii) Crònica de Bernat Desclot (1288), henceforth 'CBD', and (iii) Llibre de la Cort de Justícia de Cocentaina (1265-1296), henceforth ' $L d C J C$ '. Data from $L d F$ has been extracted from the Sí database (Pujol i Campeny, 2018), while data from the Crònica de Bernat Desclot and the Llibre de la Cort de Justícia de Cocentaina has been directly extracted from the Corpus Informatitzat del Català Antic (CICA). These three works have been chosen based on two reasons: they are clearly dated, contemporary, and they represent different genres and registers. $L d F$ and $C B D$ are two historiographical chronicles devoted to narrating the feats of Catalan-Aragonese kings, displaying a high literary register and written by civil servants of the Crown of Aragon. LdCJC consists of a compilation of legal documents recording daily transactions carried out in Cocentaina's notary, which, in spite of containing stretches of conventionalised legal text, also presents attestations of reported direct speech of laymen and laywomen from Cocentaina who used the notary.

The analysis of these texts not only reveals novel insights concerning the grammaticalisation and distribution of si and the nature of Old Catalan's left periphery, but also highlights the importance of taking into account the interaction of register variation and syntax. 
The article is organised as follows: in section 2, the different strategies for encoding positive polarity in Latin and the distribution of the manner adverb from which sí derives are presented. In section 3, analyses of sí in other Romance languages are succinctly discussed in reference to Old Catalan data, followed by section 4 , where Old Catalan data is presented and analysed. Finally, section 5 offers a summary of the findings presented throughout the article.

\section{Emphatic Positive Polarity in Latin}

It is a well-known fact that Latin did not have a positive sentential proform. Nevertheless, it had plenty of mechanisms that could convey emphatic positive polarity, among which the following particles and adverbs: ENIM (Spevak 2012), QUIDEM (Danckaert 2014), and SIC (Batllori and Hernanz 2008). This is shown in examples (1-3):

$$
\begin{aligned}
& \text { Dissimilis quidem Chares horum et factis } \\
& \text { unlike certainly Charles his and deeds.ABL } \\
& \text { et moribus sed tamen Athenis et } \\
& \text { and character.ABL but however Athens.ABL and } \\
& \text { honoratus et potens. } \\
& \text { honourable and powerful }
\end{aligned}
$$

(2)

$\begin{array}{lllll}\text { Aliud quid? } & \text { Etiam: } & \text { quando } & \text { te } & \text { proficisci } \\ \text { other what } & \text { yes } & \text { when } & \text { you.ACC } & \text { go.INF.PRES.PASS } \\ \text { istinc } & \text { putes } & \text { fac } & \text { ut } & \text { sciam. } \\ \text { from;here } & \text { think.2SG } & \text { do.2SG.PRES.IMP.ACT so } & \text { that } \\ \text { know.1SG.PRS.SBJV } & & & \end{array}$

'What else? Yes! When you think of following up from this [letter], do let me know.'

Cicero, Epistulae ad Atticum, 2.6.2.15

$$
\begin{array}{llll}
\{\text { IVPP } & \text { Heia autem } & \text { inimicos? } & \\
& \text { INTER however enemies.ACC } & \\
\text { \{ALC. } & \text { Sic est, vera } & \text { praedico. } \\
& \text { thus is true things.ACC } & \text { proclaim-1SG }
\end{array}
$$

'Iupiter: Ha! Enemies indeed?

Alcmena: It is so, I speak truly.'

Plautus, Amphytruo, 901

In examples (1-3) we can see three different lexical items used to convey positive emphatic polarity. (3) is particularly relevant for the purposes of this paper,

$1 \quad$ Unless otherwise stated, Latin translations are my own. 
since it contains the manner adverb SIC 'thus', the precursor of Modern Catalan and Modern Spanish sí, Modern Italian sì, and Modern Portuguese sim.

Apart from adverbs and particles, Latin also had syntactic strategies available for conveying emphatic positive polarity. They include V1 constructions (Devine and Stephens 2006:147) and verb echo answers to direct and indirect questions (henceforth V-echo):

(4) Context: Cicero, in his defence of Lucius Murena's dignity against the accusatory Servius Sulpicius, focuses his accusation on the humble origins of Murena's family. Cicero, in an attempt to deconstruct his arguments, projects Sulpicius' accusation on the plebeian origin of Murena's family and contrasts it with the noble origins of the accuser's family. To highlight the contrast between Sulpicius' exaltation of his family and contempt towards Murena's, Cicero sentences:

Contempsisti L. Murenae genus, extulisti tuum despised.2SG L. Murena's clan brought;forth.2SG yours 'You despised the Murena clan, you have praised yours.' Cicero, Pro Murena, 7.15, apud Devine \& Stephens (2006:147, example 5)

$\begin{array}{lllll}\text { Clodius } & \text { insidias } & \text { fecit } & \text { Miloni? } & \text { Fecit. } \\ \text { Clodius } & \text { plots.ACC } & \text { made.3SG } & \text { Milo.DAT } & \text { did.3SG } \\ \text { 'Did Claudius plot against Milo? He did indeed.' } & \\ \text { Cicero, Pro Milone, 60.3, apud Martins } & \text { (2005:179, example 3) }\end{array}$

Example (4) illustrates a case of V1 used to convey emphatic positive polarity. In the first clause, we find the verb CONTEMPSISTI in sentence initial position, in contrast with the verb in the following clause: EXTULISTI. According to Devine \& Stephens (2006:147), in these cases, the movement of the verb to sentence initial position is triggered by the presence of a positive polarity operator, which they label PosPol and which Martins (2005:178-179), following Laka (1990), identifies with the highest projection in the inflectional domain, इP. According to Martins 2005, 2013), verb movement to this projection allows for VP ellipsis, which makes structures such as verb-echo possible. The informational value of sentences with verb movement to $\mathrm{PosPol} / \Sigma \mathrm{P}$ is Verum Focus, that is, focus on the truth value of the proposition, excluding its negative counterpart (Krifka 2008; Leonetti and Escandell Vidal 2009, Batllori and Hernanz 2015). The movement of the verb to sentence initial position emphasises the positive polarity of the assertion being made and denies its negative counterpart. In (5), after a direct yes/no question, the reply provided is a V-echo answer, where the verb of the question is "echoed" or repeated. The syntax of V-echo structures is discussed at length in section 4. 


\section{Sí across the Old Romance languages}

$\mathrm{Si} / \mathrm{si}^{2}$ has received significant attention in the Old Romance literature: it has been studied in regard to Old Portuguese (Martins 2013), Old Catalan and Old Spanish (Batllori and Hernanz 2013, 2008), Old Spanish (Rodríguez Molina 2014), Old Italian (Salvi 2002; Poletto and Zanuttini 2013; Wolfe 2015; Poletto 2005, 2014), Old Neapolitan (Ledgeway 2008), Old French (Marchello-Nizia 1985; Fleischman 1991; Sitaridou 2003; Wolfe 2015; Wolfe 2018), and Old Occitan (Donaldson 2016).

Analyses of si/sí broadly fall in two groups: those that link it to the fulfilment of the V2 parameter and those that link it with the expression of positive polarity. The former stems from data from Galo-Romance and Italo-Romance varieties while the latter type of analyses clusters around Ibero-Romance varieties (the term being understood geographically). In what follows, we consider first analyses that connect si/si with the fulfilment of the V2 parameter, and then those that link si/sí with polarity.

Since the 80s, and not without controversy, several authors have proposed that the Old Romance languages went through a V2 stage during the High Middle Ages (Benincà 1984; Vanelli, Renzi, and Benincà 1986; Adams 1987; Roberts 1993; Vance 1993, 1997; Vance, Donaldson, and Steiner 2010; Salvesen 2013; Wolfe 2015b; Benincà and Poletto 2004b; Benincà 2006; Poletto 2005, 2014, Ledgeway 2007, 2008; Steiner 2014; Donaldson 2016 among others). Recent formulations of the V2 parameter establish that it is bipartite:

(6) 'A language is called a verb-second (V2) language when the finite verb is obligatorily the second constituent, either specifically in main clauses or in all finite clauses.' (Holmberg 2015:342)

Wolfe (2015) refines this definition of the V2 parameter for the Romance languages. He proposes the existence of a head in the left periphery (as described by Benincà $[2004,2006])$ that acts as a probe for finiteness features, attracting the verb. This same head is endowed with an Edge Feature (EF) that attracts a phrasal constituent to its specifier. According to his analysis, Romance varieties differ in regard to which projection acts as probe for finite features and hosts the EF: some varieties, like Old Sardinian, have it in ForceP, and hence display strict V2, since no projections over ForceP are available for hosting other material, while others, like Old Occitan, have it in FinP, and therefore, elements base-generated in the Frame and Topic fields (Benincà 2004, 2006) can precede the verb and the XP moved to SpecFinP, assuming the cartographic framework (Rizzi 1999, Benincà 2004, 2006, Benincà and Poletto 2006).

Analyses of $s i$ within V2 grammars broadly fall into three groups: (i) those that connect it to topic continuity (Fleischman 1991; van Reenen and Schløsler 2000; Salvi 2002); (ii) those that take it to be a last resort strategy for the fulfilment of the V2 requirement (Poletto 2005; Ledgeway 2008; Poletto 2014; Wolfe 2015; Donaldson 2016); and (iii) those that link with the assertion of the clause (Marchello-Nizia 1985), in line with analyses proposed for sí in the Old Ibero-Romance languages.

2 The spelling of sí/sí depends on the language: si for Old French and Old Occitan, sì for Old Italian and Old Neapolitan, and sí for Old Catalan, Old Spanish, Modern Catalan and Modern Spanish. 
Clauses that present $s i$ in Old French, Old Occitan and Old Italian varieties, share the following formal features, illustrated by Old French examples in (7-9): (i) si is always verb-adjacent, but for clitic pronouns; (ii) si is only ever preceded by material base-generated in the left periphery (in the Frame and Topic fields), and very frequently, it occurs in clause initial position, followed by the verb; and (iii) often, but not always, si correlates with topic continuity.

$\begin{array}{lllllll}\text { Adont si } & \text { atorna } & \text { li } & \text { rois } & \text { mout } & \text { rikement } & \text { se } \\ \text { then si } & \text { adorned.3sG } & \text { the } & \text { king } & \text { very } & \text { richly } & \text { his } \\ \text { sereur }(\ldots) & & & & & & \\ \text { sister } & & & & & \end{array}$

'Then the king dressed his sister up richly.'

[ForceP [Frame Field adont [TopP [ FocP $[$ SpecFinP si [Fin' atorna $[$ SpecTP li rois $[\mathrm{T},[\ldots$

Loys LII, 150-151, apud van Reenen \& Schløsler (2000:80)

Si en fu la reïne moult carrociee
si of;it= was.3SG the queen very angry
'The queen was very upset about it.'
[ForceP [Frame Field [TopP [ FocP [SpecFinP si [Fin' en fu [SpecTP la reïne [T' [...
Mort Artu, \$166, apud Benincà (2006a:64)

(9) $\underline{\mathrm{Li}} \underline{\text { rois }}$ se vest et apareille tout maintenant, the king himself dressed and got ready all now puis s' assiet en son lit, et puis fist the himself sat.3sG in his bed and then made.3sG sa serour asseoir de jouste li; si li commence his sister sit.INF of just him si to her start.3SG a demander de son estre, et ele l'en dist to ask.INF of her being and she him=of;it=told.3SG partie, et partie l'en ceile. Si demeurent part and parted.3SG him=of;it= that one si remain.3PL leanz en tieus paroles jusqu' a eure de prime. therein in your words until at hour of first 'The king got dressed and ready in the meanwhile, and afterwards he sat on his bed and then he made his sister sit next to him, and he started to ask her about her wellbeing, and she told him a part of it, and spared him the other one. And they remained talking until dawn.' Mort Artu, §50.78-83, apud Fleischman (1991:254)

In (7), si is preceded by the frame setter adont 'then', base-generated in the left periphery. It is followed by the verb, raised to the left periphery, and the subject, that remains in SpecTP. Si, in turn, satisfies the EF in FinP. In (8), si is not preceded by any other constituent, it occurs in clause initial position. As in (7), the subject of the clause remains in SpecTP, and it is $s i$ that satisfies the EF in FinP. Finally, (9) is a case in which si correlates with discourse topic continuity, but not subject continuity. In the first clause, the subject is li rois 'the king'. In the clause that follows it is sa serour 'his sister'. In the third clause, a clause with no overt subject, si appears. It is not the sister, but the king that does the talking. Therefore, there is no subject continuity with 
the preceding clause, but there is discourse topic continuity, something that is often the case when si appears.

Given its distribution (frequent in V1 clauses and always verb adjacent), several authors have proposed that it is a last resort strategy to satisfy the EF linked to the V2 constraint when no other XP can raise to the specifier of the projection that probes for finite features. Therefore it must be a maximal category, and given its lack of semantic content, an expletive (Poletto 2005; Salvesen 2013; Wolfe 2015).

In Old Spanish, the distribution and semantics of sí differed significantly from those sketched above for Old French. Batllori \& Hernanz (2008) propose that Latin SIC underwent an upward grammaticalisation process (in the spirit of Roberts and Roussou 2003) that transformed Latin SIC, a manner adverb, into a Positive Polarity Item (PPI).

According to Batllori and Hernanz (2008), SIC was reanalysed in the context of answers to direct and indirect yes/no questions involving $\mathrm{V}$-echo and verbs of support, similar to English do-support (Biberauer and Roberts 2008:34).

Holmberg (2016:52-53) states that crosslinguistically, there are two mechanisms by which answers to yes/no questions can be constructed: on the one hand, they can be a declarative clause that expresses one of the question's alternate propositions. On the other hand, they can be constructed through the spell out of a focused polarity feature, either an externally merged particle or a moved verb copied from the question, that assigns value to a polarity feature that is inherited from the question. Holmberg locates this polarity feature in a Polarity Phrase (PolP), the highest projection within the inflectional domain, as first described and labelled $\Sigma \mathrm{P}$ by Laka (1990), label to which we adhere to refer to the polarity-related projection within the inflectional domain in this article. Both strategies involve the movement of the particle or the verb to a Focus projection in the left periphery, so that the $\mathrm{CP}$ may be interpretable as a declarative sentence with a truth value, be it positive or negative. Then, $\Sigma \mathrm{P}$ can be elided because it is identical to the question's $\Sigma \mathrm{P}$ but for its truth value, which is moved to FocP and is the only new information provided is the value of the polarity feature. This is exemplified in relation to polarity particles in (10):

(10) a. Question: [ст do [тр you [ \pm Pol] want tea]

Paraphrase: "What is the value of $[ \pm \mathrm{Pol}]$ such that "you $[ \pm \mathrm{Pol}]$ want tea" is true?

Adapted from Holmberg (2016:53, fig. 1)

b. Affirmative answer: 'yes' + PolP elision

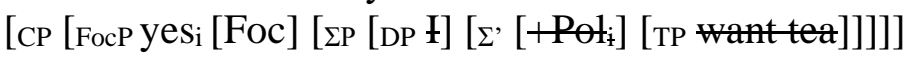

Adapted from Holmberg (2016:53, fig. 2)

c. Affirmative answer: yes + do support and VP elision

[CP [FocP yesi [Foc] [TP I [+Poli $]$ do [vP want tea]]]]]

Adapted from Holmberg (2016:61, fig. 19)

d. Negative answer: 'no'

[CP [FocP noi [Foc' $[\mathrm{Foc}]\left[\Sigma \mathrm{P}[\mathrm{DP}\right.$ you $]\left[\Sigma_{-}^{\prime}\left[\mathrm{Pol}_{i}\right][\right.$ тP-want tea $\left.\left.\left.]\right]\right]\right]$

Therefore, FocP is the projection that accommodates elements that display emphatic polarity features. Polar elements base-generated in PolP and landing in FocP are both endowed with a polar feature (positive or negative) and a [+emphasis] feature (Ballori and Hernanz 2013:21). 
Martins (2013:96) also vouches that the interaction between CP and $\Sigma \mathrm{P}$ is responsible for the encoding of emphatic positive polarity. Without committing to the existence of a specific polarity-related head in the left periphery, she argues that relative polarity features, which encode the agreement or denial ([reverse] and [same] in Farkas \& Bruce [2010] analysis) of the polarity of a clause in relation to the previous utterance, are located within the CP. In contrast, the highest functional projection within the inflectional domain, $\Sigma \mathrm{P}$, hosts absolute polarity features, [+] and [-], corresponding to [+affirmation] and [+negation]. For the purposes of this article, we hypothesise that there is a Polarity-dedicated projection in the left periphery that hosts relative polarity features and interacts with FocP. We refer to this projection as PolP, as opposed to $\Sigma \mathrm{P}$, the highest head of the inflectional domain, which hosts absolute polarity features. $\Sigma \mathrm{P}$ can be valued, as we have seen above, either by particles basegenerated in this projection, which then undergo movement to PolP to value relative polarity features or by verb movement. We do not deny the possibility that relative polarity features might be a property of FocP, which could be the case if we assume a feature staking analysis. However, the visualisation of the interaction between absolute and relative polarity features is simpler by postulating a PolP head in the left periphery. Backing the existence of a polarity-dedicated position in the left periphery, we find Rodríguez-Molina's (2014) analysis of verb position in Old Spanish, which proposes that this variety had V-to-Pol movement, with Pol located above FinP, in the left periphery.

After these theoretical considerations, examine (11) and (12): the former is an instance of a V-echo answer to a yes/no question in Old Spanish and the latter, a case of a do-support answer, also to a yes/no question, supported by sí:

$\begin{array}{lll}\text { Celestina: } & \text { ¿Quiereslo } & \text { saber? } \\ \text { Celestina } & \text { want.2SG=it } & \text { know.INF } \\ \text { Sempronio: } & \text { Quiero. } & \\ \text { Sempronio } & \text { want.1SG } & \\ \text { 'Celestina: Do you want to know it? }\end{array}$

Sempronio: I certainly do.'

Celestina, 1.110, apud Rodríguez Molina (2014:873)

(12) Yo le dije todo lo que había pasado.

I to;him= said.3sG all it that had.3SG happened

Mandome me fuesse a Écija.

ordered.3SG=to;me I.ACC $=$ go.3SG.PST.SBJ to Écija

Dije que sí haría

said.1SG that yes do.1SG.COND

'And I told him everything that had happened. And he told me to go to Écija.

And I said that I certainly would.'

Vida, 316, apud Rodríguez Molina (2014:876)

In (11), the verb querer 'to want' that appears firstly in the direct yes/no question and is then repeated in the affirmative answer to the question. In (12), the verb of the indirect question, irse 'to leave', is not repeated. Instead, the answer contains the verb hacer, 'to do', which refers anaphorically to the predicate of the first character's intervention. According to Batllori and Hernanz (2013:14), do-support and 
V-echo structures involve the raising of adverb sí (a variant of the manner adverb así 'thus') to the left periphery through focalisation after being base-generated in VP. The adverb eventually becomes base-generated in the left periphery, after being grammaticalised as an EPPA:

$$
\begin{aligned}
& \text { a. }[\mathrm{CP} \ldots[\mathrm{FocP} \ldots[\mathrm{PolP} \ldots[\mathrm{TP} \ldots[\mathrm{vP} \text { fago } \quad \text { así }]]]]
\end{aligned}
$$

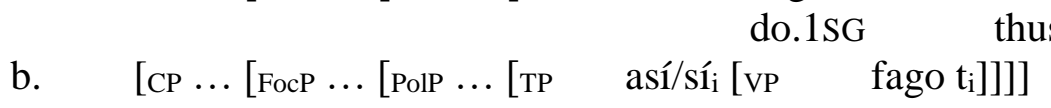

$$
\begin{aligned}
& \text { thus do.1sG } \\
& \text { c. } \quad\left[\mathrm{CP} \ldots\left[\text { [FocP así/síi } i_{i} \quad\left[\mathrm{PolP} \mathrm{t}_{\mathrm{i}}\left[\mathrm{TP} \ldots\left[\mathrm{vP} \text { fago } \mathrm{t}_{\mathrm{i}}\right]\right]\right]\right]\right] \\
& \text { thus/yes do.1SG } \\
& \text { d. } \quad[\mathrm{CP} \ldots[\mathrm{FocP} \quad \text { sí } \quad[\text { PolP [T⿱ [VP }]]]]]
\end{aligned}
$$

From Batllori and Hernanz (2008:14)

As it can be seen in (13), sí starts off as a manner adverb in its base-generated position in VP, and through a process of fronting to FocP to receive a Verum Focus reading, it grammaticalises as a positive polarity marker. As such, it is no longer moved but base-generated in PolP in the left periphery, to then be focalised in FocP, locus of emphatic features that allow it to gain scope over the clause (Rizzi 1997; Holmberg 2001; Batllori and Hernanz 2008).

Rodríguez Molina (2014) builds on Batllori and Hernanz's (2013) analysis of sí in Old Spanish. Starting from Martins' (2013) classification of the Romance languages based on whether verb movement to PolP is available or not, he establishes that Old Spanish, like Modern Galician and Modern Portuguese, had verb movement to PolP associated to the marking of assertive force, with the difference that he locates PolP in the left periphery, while Martins locates it in the inflectional domain, coinciding with Laka's (1990) $\Sigma$ P. The trigger of movement to $\Sigma$ P/PolP (depending on the author) are the strong features hosted in this head, which have to be checked by the verb overtly moving to it in positive declarative clauses.

In languages where $\mathrm{PolP} / \Sigma \mathrm{P}$ attracts the verb, certain syntactic structures become available: namely, V-echo answers and answers with do-support. Both structures involve the elision of TP, possible since it is identical to that of the question answered by the V-echo or do-support answer. The elision of TP is made apparent by the lack of clitics intervening between si and the verb and the lack of postverbal subjects that would otherwise be expected (Martins 2013:109).

The possibility of generating V-echo and do-support answers correlates with the lack of emphatic positive polarity clauses in which Force is spelled out as que 'that'. If a language does not have V-to-PolP, it will have a positive sentential proform that can take a CP headed by que 'that' as a complement. This is summarised in Table 1 .

\begin{tabular}{|l|l|}
\hline $\begin{array}{l}\text { V-to- } \mathbf{\Sigma P} / \text { PolP } \\
\text { Old Spanish, Modern Galician, Moder } \\
\text { Portuguese }\end{array}$ & $\begin{array}{l}\text { No V-to- } \mathbf{\Sigma P} / \mathbf{P o l P} \\
\text { Modern Spanish, Modern Catalan }\end{array}$ \\
\hline + verb echo answers & - verb echo answers \\
\hline+ do-support answers & - do-support answers \\
\hline+ sí (que) & + sí(que) \\
\hline
\end{tabular}


Table 1 - Features of languages with V-to-Pol vs. features in languages without $V$ to-Pol

In Old Spanish, V-echo answers can be reinforced by the particle sí. They require the verb to move from $\mathrm{Pol}^{\circ}$ to $\mathrm{Foc}^{\circ}$ and si to reinforce the answer, located in SpecFocP. According to Rodríguez Molina (2014), this allows for the elision of FocP's complement, as shown in (14):

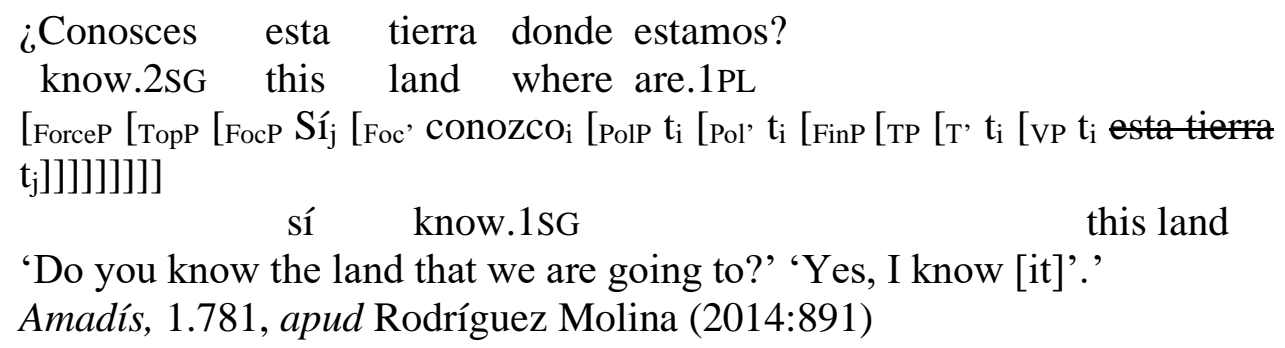

Do-support answers are by no means a phenomenon exclusive to Old Spanish: they are also found in other Old Romance languages (Benincà and Poletto [2004a] on Monnese, and Roberts [1993] on Old French). In cases of do-support, clausal structure is akin to that of V-echo structures: the verb raises to from TP to FocP through PolP. FocP's complement is elided and sí can co-occur with it to convey emphasis:

$$
\begin{aligned}
& \text { "Desto que nos abino, que uos pese, señor." } \\
& \text { this that to; us }=\text { came.3PL that to; } y o u=\text { burdens lord } \\
& \text { Respondio el Rey: "si fago, sin salve Dios!". } \\
& \text { answered.3SG the King yes do.1SG without save.PRES.SUBJ.3SG God } \\
& \text { [ForceP [TopP [FocP Síj } \left.\left.\left.\left.i_{j} \text { PolP } t_{j} \quad \text { fago }_{i}\left[\text { FinP [тP } t_{i}\right]\right]\right]\right]\right] \text { sin salve Dios!”. } \\
& \mathrm{Si} \text { do.1SG without save.3SG.PRS.SBJ God } \\
& \text { "What has happened to us should sadden you, lord'/ The King replied: 'yes }
\end{aligned}
$$

From (14) and (15), it can be established that both structures involve V-to-Pol in unmarked main clauses (Rodríguez Molina 2014; Sitaridou 2019), subsequent movement to FocP to receive emphasis, and the elision of FocP.

Since Old Spanish was a language that involved V-to-Pol to mark positive assertiveness (Rodríguez Molina 2014; Sitaridou 2019), following Martins (2013) classification of the Romance languages in relation to this property, it is not expected for it to have a positive sentential proform. Indeed, this is the case, since sí had not yet been grammaticalised and the strategy to encode emphatic positive polarity was the raising of the verb from T-to-Pol-to-Foc.

In this section, we have overviewed analyses of si in Old Romance languages, focusing on Old Spanish. It has been established that in Old Spanish, sí had not yet been grammaticalised as an emphatic polarity particle. Instead, it appeared only to reinforce the expression of positive polarity in V-echo and do-support structures.

\section{Sí in Old Catalan}


The distribution of Old Catalan $s \imath^{\hat{3}}$ differs substantially from the distribution of $s i$ in the Old Romance languages reviewed in the previous section. Old Catalan data suggests that in this language, sí behaved in a more innovative manner than in the other varieties, having not only already been grammaticalised as an EPPA by the $13^{\text {th }}$ century, but also being already used as a positive sentential proform. Firstly, we consider Old Catalan against Martins' (2013) classification of the Romance languages. Secondly, the different contexts in which sí is found are evaluated and their syntax its described.

Martins (2013), as shown in Table 1, establishes a correlation between the existence of V-to- PolP with the availability of V-eco and do-support answers. In Pujol i Campeny (2018), the lack of verb movement to the left periphery in unmarked main declarative clauses in Old Catalan is extensively proved: Old Catalan, like its modern counterpart, was an SVO language in which the verb remained in the inflectional domain in unmarked declarative clauses. Not only did Old Catalan differ from Old Spanish and Old and Modern Portuguese in this respect, but it also differed from them in having two positive sentential proforms: one shared with Old Occitan, ${ }^{4}$ òc, and sí.

Oc derives from the Latin demonstrative pronoun HOC, 'this'. In LFRJ, it is exclusively found as a sentential proform, and never in conjunction with V-echo or do-support structures, nor as an EPPA that occurs in fully fledged clauses or with a CP as its complement: $\grave{c} c$ only ever appears as the answer of yes/no questions, as illustrated in examples (16) and (17):

(16) E dixem -li: "Eres tu ab lo comenador?" and said.1PL=to;him are.2SG you with the head knight e él dix: "seyor, och". and he said.3sG lord yes 'And we said to him: 'Were you with the head knight?' and he said 'Lord, yes'.'

$L d F$, fol. $103 r, 1.16$

(17) E·1 comte responia-li: 'Sèyer, hoc. Per Déu, merçè!' and; the count answered=to.him lord yes by God mercy 'And the count answered him: 'Lord, yes. By Lord, mercy!'.' $C B D$, p. III.33, 1.16

Apart from $\grave{c} c$, in Old Catalan, the particle sí could already express positive polarity. Instances of polarity-linked sí in $L d F, C B D$ and $L d C J C$ can be classified in 5

3 While in Modern Catalan and Modern Spanish, the convention is to distinguish emphatic positive polarity sí from the conditional conjunction si orthographically by means of a diacritic, this is not always the case in Old Catalan and Old Spanish texts. Here, I will respect the editors' decision in adding the diacritic to the emphatic polarity particle, and I will rely on the glosses to show the difference in meaning.

$4 \quad$ In the texts used for the purpose of this article, several spellings of $\partial c$ are attested: $h o c$, etymologically connected to the Latin demonstrative pronoun HOC, and òch, with the Old Catalan spelling of word-final $/ \mathrm{k} /$. 
categories: (i) occurrences of sí in fully fledged main clauses; (ii) sí V-echo; (iii) sí dosupport; (iv) sí in infinitival clauses; and (v) sí as a sentential proform. Table 2 shows the frequency in which each of these structures is attested in each of the works: ${ }^{56}$

\begin{tabular}{|l|l|l|l|l|l|}
\hline Syntactic context & $\begin{array}{l}\text { Llibre dels } \\
\text { Fets }\end{array}$ & $\begin{array}{l}\text { Crònica de } \\
\text { Bernat } \\
\text { Desclot }\end{array}$ & $\begin{array}{l}\text { Llibre de Cort } \\
\text { de Justícia de } \\
\text { Cocentaina }\end{array}$ & Total & $\%$ \\
\hline $\begin{array}{l}\text { Positive Polarity } \\
\text { sí in fully fledged } \\
\text { main clauses }\end{array}$ & 19 & 27 & 1 & 47 & $36 \%$ \\
\hline Sí V-echo & 7 & & & 7 & $5 \%$ \\
\hline Sí do-support & 2 & 2 & 1 & 5 & $4 \%$ \\
\hline Sí + Inf & - & - & 3 & 3 & $2 \%$ \\
\hline Proform & 1 & 1 & 65 & 67 & $52 \%$ \\
\hline Total & 29 & 30 & 70 & 129 & $100 \%$ \\
\hline
\end{tabular}

Table 2 - Distribution of sí in LdF, CBD and LdCJC

As shown in Table 2, the distribution of sí differs substantially depending on the text's genre: in $L d F$ and $C B D$, both chronicles, sís occurrences are strikingly more frequent in fully fledged main clauses, while in $L d C J C$ it is the proform use of sí that is the most attested. Sí in V-echo structures is only attested in $L d F$, while $s i ́$ + INF is only found in $L d C J C$. Si + do support is found across the three texts while displaying low frequency.

In what follows, we describe each of the syntactic contexts in which sí is found.

\subsection{Sí in fully fledged clauses}

There are 47 occurrences of sí as a positive polarity particle in fully fledged clauses (with no VP elision) across the three works consulted. ${ }^{7}$ Syntactically, these clauses present the following features: (i) sí is always verb adjacent, (ii) object and adverbial clitics can appear between sí and the verb, and (iii) topical material can precede sí. This is illustrated in examples (18)-(21):

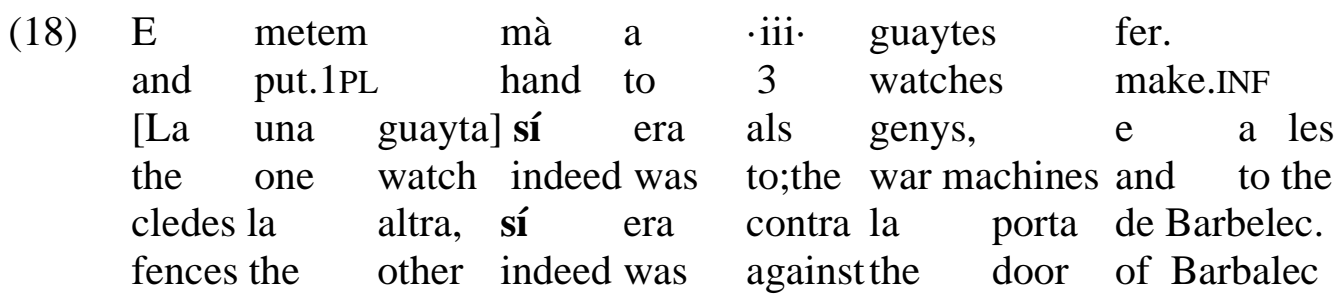

5 We have not been able to find any cases of V-echo or do-support without sí in the works consulted. This does not exclude this possibility elsewhere.

6 The fixed expression 'si Déus ajut', found in all Old Gallo Romance languages as well as in Old Spanish, is not considered in this article given its idiomatic and fixed nature.

$7 \quad S i$, analysed as an EPPA in declarative clauses, will be translated as 'indeed', 'certainly' and emphasis on auxiliaries depending on which choice is more idiomatic in English. 
'And we decided to set up three watching posts. One, WAS next to the catapults, and at the wooden fortress, there WAS the other, against the gate of Barbalec.'

$L d F$, fol. 48 r, 1.19

(19)

$\begin{array}{lcllll}\text { Si homes del món àn } & \text { mala fama, } & \underline{\text { nós }} & \text { sí } \\ \text { if } & \text { men of;the } & \text { world have.3PL bad reputation } & \text { we } & \text { indeed } \\ \text { la } & \text { havem } & \text { bona. } & & \\ \text { it } & \text { have.1PL } & \text { good }\end{array}$

'If some men in the world have bad reputation, ours is indeed good.'

$L d F$, fol. 29r, 1.10

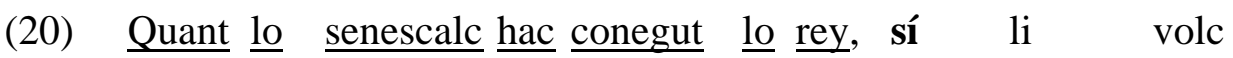

when the butler has met the king indeed to; him= want.3sG

besar la mà, mas lo rey no ho volc.

kiss.INF the hand but the king not it wanted.3SG

'After meeting the king, the butler certainly wanted to kiss his hand, but the king did not want him to.'

$C B D$, p. III, 162, 116

(21) E anch per aquesta paraula nengú no.s moch, and never for this speech no one not;himself $=$ moved.3SG

e sí la hoïren tots.

and sí it heard.3PL all

'And no one at all budged because of this speech, and they all had indeed heard it.'

$L d F$, fol. 49 r, 1.13

In (18), sí occurs between the topical subject, la una guayta, 'one of the watches', and the verb era 'it was'. In (19), sí is preceded again by the clause's subject, nós 'we'. In contrast, in (20), sí is preceded by a temporal embedded clause, located in the Frame Field. The indirect object clitic pronoun $l i$ 'to him' appears between sí and the verb. In (21), an object clitic intervenes between sí and the verb, and the clause's subject, tots 'all' appears postverbally. Therefore, up to this point, it can be established that the distribution of sí in Old Catalan differs significantly from the description of the distribution of sí in Old Spanish in that (i) sí can be preceded by topical material; (ii) there is no elision of projections below it given that postverbal constituents may follow the sí $\mathrm{V}$ sequence; and (iii) clitic pronouns can appear between si and the verb.

All instances of sí in fully fledged main clauses have one thing in common: they occur within the scope of a non-veridical licensing environment (Giannakidou 1998, 1999, 2001, 2008 and subsequent). Giannakidou's non-veridicality model accounts for the distribution and licensing of polarity items, defined as follows:

(22) Polarity item

a. A polarity item $\alpha$ is an expression whose distribution is limited by sensitivity to some semantic property $\beta$ of the context of its appearance.

b. B is non-veridicality. 
Giannakidou defines non-veridical operators as in (23):

"An operator Op is non-veridical iff the truth of Op p in c does not require that $\mathrm{p}$ be true in some such model in c". Giannakidou (1998:112)

In other words, a non-veridical operator does not require a proposition to be true in some of the models (set of worlds) of a specific context. Most importantly, a non-veridical operator does not entail the falsity of the proposition.

Polarity Items (PIs) fall in two different categories: Negative Polarity Items (NPIs), and Positive Polarity Items (PPIs). However, here we are concerned with PPIs, since sí comes to be a PPI in the Modern Romance languages. PPIs, as shown by Ernst (2009), do not merely occur in assertive contexts: they can also appear in non-veridical ones. Giannakidou (1998) identified the following non-veridical contexts as potential licensors of PIs:

(24) Non-veridical contexts in which PIs are licensed

i. Monotone quantifiers

ii. Modal verbs

iii. Intentional verbs

iv. Non-declarative clauses: interrogative, imperative and exclamative clauses.

v. Protasis of conditionals, conditional clauses, before-clauses

vi. Habitual tenses

vii. Future tenses

viii. Non-veridical implicatures

Invariably, all the Old Catalan instances of sí in fully fledged main clauses occur within the scope of non-veridical licensors. This is shown in (25)-(31), where several cases of si that occur in fully fledged main clauses are reproduced with their licensing context. With the context in hand, it is possible to identify the non-veridical licensor of sí, which may be explicitly expressed in the context or implied (see Giannakidou [1998] for an overview of indirect licensing of PIs):

La dona féu
the woman made.3SG search.INF knights who

'The woman searched for knights who could exculpate her by fighting on her behalf and she could not find who would want to fight for her. And she had indeed made great gifts and paid homage to many knights (...).' $C B D$, II. 47 , line 18 
Licensor: implicature derived from the preceding clause, where it is stated that no one would fight for her, implying that she had not made gifts and paid homage to knights who would.

(26) Context: Certa cosa és que·1 nostre naximent se féu per vertut de Déu, car no.s volien bé nostre pare ni nostra mare,

'It is indeed true that our birth took place by virtue of God, since our father and mother did not love each other,'

e sí fo volentat de Déu que nasquem en

and sí was will of God that be born.1PL.PRS.SBJV in

aquest món.

this world

'And indeed, it was God's will that we were born in this world.'

$L d F$, fol. $28 \mathrm{r}, 1.15$

Licensor: Implicature derived from the preceding clause. Since his father and his mother did not love each other, his birth was unlikely to happen.

(27) E si volets saber com foren albergats, and if want.2PL know.INF how were.3PL sheltered

sí $\cdot$ ls mès hom en una esgleya $(\ldots)$

indeed;them put.3SG one in one church

'And if you want to know how they were sheltered, they were indeed put in a church (...)'

$C B D$, p. III. 106, line 18

Licensor: preceding protasis.

(28) Si homes del món àn mala fama, nós sí

if men of;the worldhave.3PL bad reputation we sí

la havem bona.

it have.1PL good

'Even if some men of the world have bad reputation, ours is certainly good.'

$L d F$, fol. 29 r, 1.10

Licensor: preceding protasis.

(29) E metem mà a ·iii-guaytes fer.

and put.1PL hand to 3 watches make.INF

La una guayta sí era als genys, e a les cledes

the one watch sí was to;the war machines and to the fences

la altra, sí era contra la porta de Barbelec.

the other sí was against the door of Barbalec

'And we decided to set up three watching posts. One, was certainly next to the catapults, the other was certainly at the wooden fortress, which was against the gate of Barbalec.'

$L d F$, fol. 48 r, 1.19

Licensor: monotone quantifiers 'three' and 'una'.

(30) E anch per aquesta paraula nengú no·s moch, and never for this speech no one not;himself= moved.3sG 
e sí la hoïren tots.

and sí it heard.3PL all

'And no one at all budged because of this speech, and they all had indeed heard it.'

$L d F$, fol. 49 r, 1.13

Licensor: implicature derived from preceding clause: since no one moved after the speech, it is possible to infer that they had not heard it.

$$
\begin{aligned}
& \text { E ja.s fos que nós haguéssem } \\
& \text { and already be.3SG.PST.SBJV that we had.1PL.PST.SBJV to entry.INF } \\
& \text { en guerra ab lo rey de Castella, ab tot açò, } \\
& \text { in war with the king of Castille with all this } \\
& \text { sí.ns era bo el pleyt per .iii raons: } \\
& \text { sí=to;us was good the dispute for } 3 \text { reasons } \\
& \text { 'And even if we had to wage war against the king of Castille, with all this, } \\
& \text { the conflict would certainly be good for us for three reasons.' } \\
& L d F \text {, fol. } 71 \mathrm{r}, 1.7 \\
& \text { Licensor: preceding protasis, introduced by the concessive conjunction } \\
& \text { jatsia 'even if'. }
\end{aligned}
$$

As it can be seen in examples (25-31), sí consistently occurs within the scope of a non-veridical licensor, be it overtly expressed or implied. Sí is used to ascertain the truth of a declarative clause against the non-veridical background; therefore, it can be established that in fully fledged clauses, sí is already a PPI licensed by non-veridical contexts in fully fledged clauses.

In terms of clausal structure, Old Catalan sí in fully fledged clauses requires an analysis that can account for its strict adjacency to the verb, with clitics being the only element that can intervene between them. Furthermore, it needs to allow for the presence of topical elements (see (19) and (20)) and the possibility of VP material occurring postverbally.

Old Catalan, like Modern Catalan and Modern Spanish, had a type of focalisation linked to drawing emphasis to the positive polarity of a proposition and the rejection of all negative alternative readings of the same proposition referred to as Verum Focus (Krifka 2008; Leonetti and Escandell Vidal 2009:182).

In Pujol i Campeny (2018), following Batllori and Hernanz's (2015) analysis for this construction in Modern Catalan, I propose that the underlying syntactic structure of Verum Focus is connected to that of emphatic positive polarity, since it is also licensed in non-veridical contexts (Batllori and Hernanz 2015:293). ${ }^{8}$ In Verum Focus (i) a constituent or head is fronted to the left periphery, to SpecFocP; (ii) the

$8 \quad$ While in Old Catalan Verum Focus or Weak Focus Fronting, as labelled by Batllori and Hernanz $(2009,2015)$ could apply to a variety of constituents, in Modern Catalan it is restricted to Quantifier Phrases (Quer 2002) and requires the right dislocation of postverbal elements in order to avoid nuclear stress befalling upon them, which would generate infelicitous clauses. The categorical restrictions of verum Focus or Weak Focus Fronting in Modern Catalan has favoured the grammaticalisation of more positive polarity particles than in other varieties where it is still available, such as Modern Spanish. 
verb raises to the left periphery to value PolP, and subsequently to FocP to receive emphasis; and (iii) no constituent can intervene between the fronted constituent and the verb since they occupy adjacent positions within the same projection, clitic pronouns being the exception, given that they are phonologically dependent on the verb in Modern Catalan and Spanish. This is illustrated in example (32): ${ }^{9}$

Licensing context

a. Negative question:

No ens diràs res de la feina nova?

not to;us= say.2sG nothing of the job new

'And won't you tell us anything about your new job?'

Paraphrase: I thought that you were going to tell us about your new job, please confirm that I am right.

b. $\left[\mathrm{CP} \ldots\left[\mathrm{PolP}\left[\mathrm{Pol},[\mathrm{Pol} \pm] \ldots\left[\Sigma \mathrm{P}\right.\right.\right.\right.$ no[SpecIP proj $\left[\mathrm{TP}\right.$ ens diràsi $\left[\mathrm{vP}\left[\mathrm{SpecvP}_{\mathrm{P}} \mathrm{pro}_{\mathrm{j}}\right.\right.$ [vp [DP res de la feina nova $\left.\left.\left.\left.\left.\left.\left.\left.\left.\left[\mathrm{v} \mathrm{t}_{\mathrm{i}}\right]\right]\right]\right]\right]\right]\right]\right]\right]\right]$

c. Answer with Focus Fronting

UNA COSA us en diré: és a la Generalitat. one thing to;you. $\mathrm{CL}=$ of;it. $\mathrm{CL}=$ say.1SG is at the Generalitat 'One thing I shall tell you about it: it is in the Generalitat.'

d. [CP ... [FocP [SpecFocP UNA COSA [F' [Foc us en diré $]$ ] [PolP [ $\left[\mathrm{Pol}\right.$ ' $\left.\left[\mathrm{Pol} \mathrm{Pol}+\mathrm{t}_{\mathrm{i}}\right]\right]$ [TP [SpecTP $\left.\left.\left.\left.\left.\left.\left.\operatorname{pro}_{\mathrm{j}}\left[\mathrm{T},\left[\mathrm{T} \mathrm{t}_{\mathrm{i}}\right]\left[\mathrm{vP}\left[\mathrm{Spec}, \mathrm{vP} \operatorname{pro}_{\mathrm{j}}\left[\mathrm{v},\left[\mathrm{v} \mathrm{t}_{\mathrm{i}}\right]\right]\right]\right]\right]\right]\right]\right]\right]\right]\right]\right]$

Modern Catalan

As shown in (32a), the licensing context of the Verum Focus structure contains an unvalued Polarity feature, which is valued through Verum Focus in the answer, as in (32c). Old Catalan Verum Focus follows the same pattern, with the difference that constituents other than Quantified Phrases are susceptible to be fronted, as is the case in (33), where the pronoun AÇÒ, the direct object of the verb diré 'I will say', is fronted:

Implied negative question, paraphrase:

I thought that you were going to tell me what you think on this matter.

Please, confirm that I am right.

Answer:
a. 'AÇÒ us
this to;you.CL= say.1SG.FUT I
'I wILL tell you this.'
$L d F$, fol. 29 r, 1.8

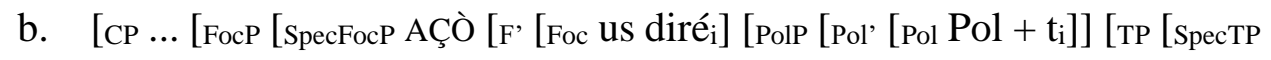 $\left.\left.\left.\left.\left.\mathrm{yo}_{\mathrm{j}}\left[\mathrm{T},\left[\mathrm{T} \mathrm{t}_{\mathrm{i}}\right]\left[\mathrm{vP}\left[\mathrm{Spec}, \mathrm{vP} \operatorname{pro}_{\mathrm{j}}\left[\mathrm{v},\left[\mathrm{v} \mathrm{t}_{\mathrm{i}}\right]\right]\right]\right]\right]\right]\right]\right]\right]\right]$

If the parallel between the distribution of si and Verum Focus is brought further from their common triggers, sí can be taken to require verb movement to the left periphery so as to value [+Pol] and reject other potential readings of the proposition. This being the case, the structure of a clause containing sí would be the following:

$9 \quad$ The focalised constituent appears in SMALL CAPS. 
\begin{tabular}{llllllll} 
b. E & anch & per & \multicolumn{2}{l}{ aquesta paraula } & nengú no.s & moch, \\
and & never & for & this speech & no one & not=himself moved.3sG \\
e & sí & la & hoïren & tots. & & & \\
and & sí & it & heard.3PL all & &
\end{tabular}

'And no one at all budged because of this speech, and they all had indeed heard it.'

$L d F$, fol. 49 r, 1.13

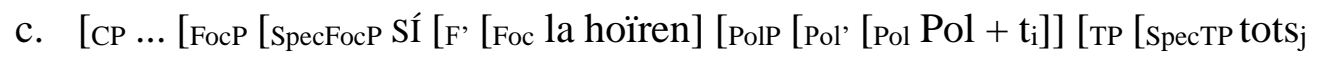

$\left.\left.\left.\left.\left.\left.\left.\left[\mathrm{T}^{\prime}\left[\mathrm{T}_{\mathrm{i}}\right]\left[\mathrm{vP}\left[\mathrm{Spec}, \mathrm{vP} \operatorname{pro}_{\mathrm{j}}\left[\mathrm{v},\left[\mathrm{v} \mathrm{t}_{\mathrm{i}}\right]\right]\right]\right]\right]\right]\right]\right]\right]\right]\right]\right]$

This being the structure of main clauses containing sí, the need for adjacency between sí and the verb is accounted for. Since sí, a PPI, asserts the 'positiveness' of the clause against the non-veridical context by valuing relative polarity clauses, it is not incompatible with the spelling out negation in the lower polarity head, $\Sigma \mathrm{P}$, as is shown in section 4.5. Furthermore, this proposal has an added advantage: it can account for the emphatic nature of si and for the fact that there is no VP ellipsis, a feature that derives from independent V-to-Pol movement, as it is shown in the following sections.

\subsection{Verb Echo in Old Catalan}

In $L d F$, we identified 7 cases of sí $\mathrm{V}$-echo as answers of yes/no questions, while no instances of $\mathrm{V}$-echo were found in either $C B D$ or $L d C J C$. No cases of $\mathrm{V}$-echo are found without sí. Sí V-echo answers are also attested in Old Spanish (Rodríguez Molina 2014), where they presented the following features: (i) clitics could not appear between si $i$ and the verb, and (ii) they present VP ellipsis, since they never contain postverbal constituents. Martins (2013) and Rodríguez Molina (2014) connect the availability of these structures to whether a language has verb movement to PolP in unmarked assertive clauses, which legitimises VP ellipsis in emphatic polarity contexts: once the verb climbs to $\mathrm{Foc}^{\circ}$ to receive emphasis, FocP can elide its complement given that it is identical to that of the question that it answers. Regarding the lack of clitics intervening between sí and the verb, this author suggests that sí, still an adverb in Old Spanish, incorporates with the verb in TP on its way to the left periphery (Rodríguez Molina 2014:891). It is by virtue of this incorporation of sí to the verbal head that clitics cannot intervene between them. It could also be suggested that the lack of clitics derives from the VP ellipsis and their traces not being spelt out in VP. VP ellipsis also accounts for the lack of topical subjects in V-echo answers: since the VP is elided, they cannot be moved to the left periphery.

In $L d F$, si $\mathrm{V}$-echo answers display the same features as Old Spanish. However, there is an important difference: while Old Spanish could generate V-echo answers without the presence of sí, as shown in (14), this possibility is not attested in Old Catalan, as it can be seen in (35-37):

$$
\begin{aligned}
& \text { E nós resposem que: "Ço que nós n' avem feyt, que } \\
& \text { and we answered.1PL that this which we of;it=have.1PL done that } \\
& \text { u havem feyt ab dret", e que neguna esmena no li } \cdot n \\
& \text { it=have.1PL done with right and that no amend not to;it=of;it } \\
& \text { faríem. E éls dixeren que sí faéssem, que aquela } \\
& \text { do.1PL and they said.3PL that si do.1PL.PRS.SBJV that that }
\end{aligned}
$$


esmena que nós faríem a él seria molta (...). amend that we do.1PL to him be.3SG.COND much

'And we answered that: 'What we have done of it, we have done rightfully, and that we would not make any corrections to it'. And they said that yes, we would do [make a correction], that the correction that we would make would be much for him.'

$L d F$, fol. 13 r, 1.21

E, hoïdes les paraules, respòs Don Nuno e dix -li:

and heard the words answered.1PL Sir Nuno and. said-3sG=to;him

'En açò que vós deïts que no tenits al

in this that you say.2PL that not have.2PL to;the

rey nostre gran tort, sí tenits, quan li presés

king ours great offence indeed have.2PL when to;him take.2SG

una tarida de son regne.

a boat of his kingdom

'And, after hearing these words, Don Nuno answered back and said to him:

'What you say that you have not committed a great offence against our king, yes you have, when you have taken a boat from his kingdom'.'

$L d F$, fol. $45,1.21$

(37) E nós volguem saber dels altres si eren and we wanted.1PL know.INF of; the others if were.3PL en aquel consel, e atorgaren tots que sí eren. in that meeting and decided.3PL all that indeed were.3PL 'And we wanted to know whether the others were in that meeting and they all said that they were indeed.'

$L d F$, fol. $104 \mathrm{v}, 1.26$

In (35-37) Old Catalan clauses with V-echo, sí is always present. In (35), Vecho appears in reaction to a negative statement and reverses its polarity. In (36), the sí V-echo answer also reverses the polarity of the preceding statement, overtly negative. Finally, in (37), we can see that the licensing context is an indirect question introduced by $s i$ 'whether'.

From these examples, it can be established that Old Catalan sí V-echo does not only occur as an answer to direct questions: it can be licensed by non-veridical contexts, as it was the case with sí in fully fledged clauses. Secondly, as we can see in (37), sí V-echo can also appear within indirect reported speech: it appears within a complement clause introduced by the subordinator que 'that'. ${ }^{10}$

Examples (38) and (39) constitute a minimal pair between a sí V-echo case in (38), and a parallel example with no sí V-echo, in (39):

(38) E nós resposem que: 'Ço que nós n' avem feyt, que and we answered.1PL that this which we of;it.CL=have.1PL done that

10 Complement clauses have been shown to crosslinguistically display root phenomena (Hooper \& Thompshon 1973; Haegeman 2003; Haegeman 2009; Haegeman 2010 and subsequent). 


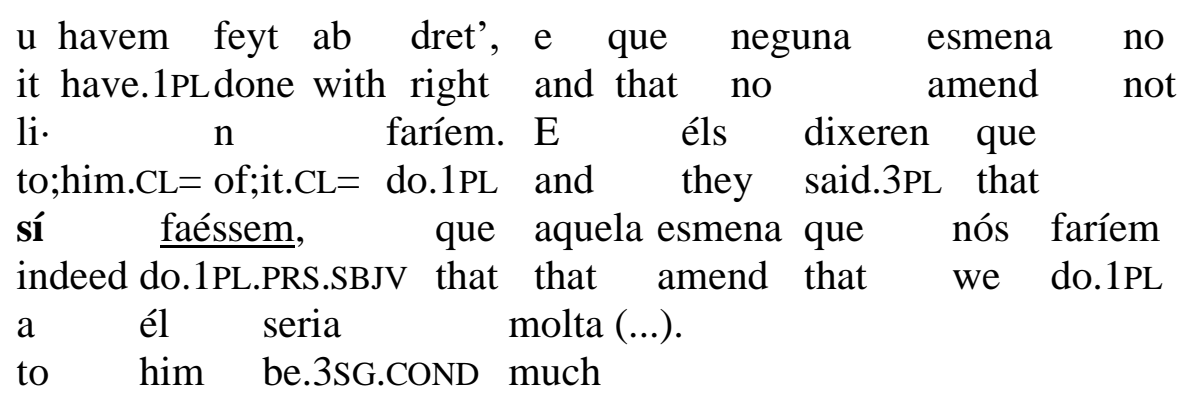

'And we answered that: 'What we have done of it, we have done rightfully, and that we would not make any corrections to it'. And they said that yes, we would do [make a correction], that the correction that we would make would be much for him.'

$L d F$, fol. 13 r, 1.21

(39)

E pregam-lo que (...) él que romangués en nostre
and begged.1PL=to;him that he that remained in our
loch en Maylorques, e que manaríem a als cavallers
place in Mallorca and that ordered.1PL.COND to; the knights
$\mathrm{e}$ a tots los altres hòmens que faessen per él
and to all the other men that do.3PL.PST.SBJV for him
axí con farien per nós. E él dix -nos que u faria.
as do.3PL.COND for us and he said=to;us that it do.3SG.COND
'And we begged him to remain in Mallorca on our behalf, and that we would
order the knights and all the other men that they would act towards him as
they act towards us. And he said that he would do it.'
$L d F$, fol. $57 \mathrm{v}, 1.5$

In (38) (a repetition of (35) for convenience), sí V-echo appears in an embedded clause, complement of dixeren 'they said'. In the immediate context, the statement of the embedded complement clause containing sí had been overtly denied. In contrast, in (39), the verbum dicendi dix-nos 'he told us' reports the answer to a previous command. The complement echoes the verb of the command, but sí is absent and an object clitic pronoun occurs proclitically, producing a positive answer to the command. This minimal pair allows us to safely reach the conclusion that sí is only used to encode emphatic positive polarity, and not simply positive polarity, which could be conveyed by means of unmarked declarative clauses with no overt negation. What is then the structural difference that accounts for the fact that sí can co-occur with object clitics in fully fledged clauses conveying positive polarity while it cannot in V-echo cases? Before attempting to answer this key question, we need to consider cases of do-support in Old Catalan, given that they pattern syntactically with V-echo and that they are an important piece of the positive polarity puzzle.

\subsection{Do-Support}

Examples (40-42) reproduce three cases of sí do-support found in $L d F$ and $C B D$. Structurally, they are very similar to si $\mathrm{V}$-echo clauses: there is no material intervening between sí and the verb, not even clitics. All sí + do-support cases occur within reported speech sequences, be them direct or indirect. 
(40) Context: King Alphonse of Aragon has been killed in battle with no heir. Aragonese knights ask his brother, Ramir II, a monk, to take up the role. He replies:

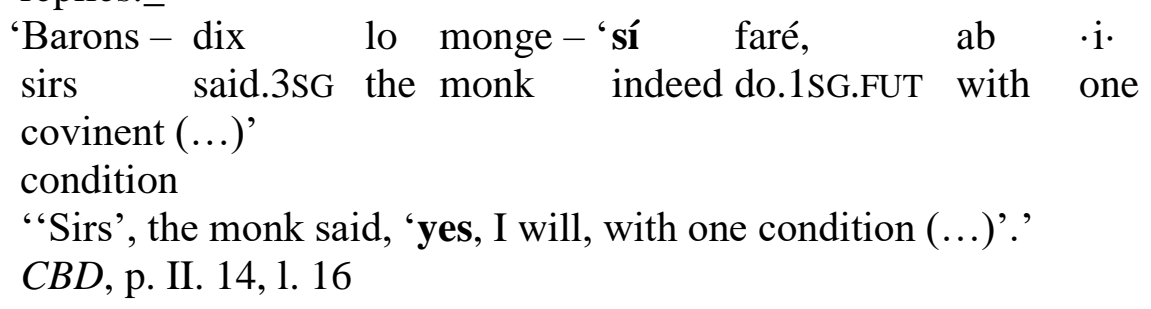

(...) sol que la guardassen de les sagetes. E nós

only that her kept.3PL from the arrows and we

dixem-li que sí faríem.

said=to; her that sí do.1PL.COND

'(...) as long as they would guard her from the arrows. And we said to her that we would indeed do it.'

$L d F$, fol. $24 \mathrm{v}, 1.14$

(42) E, quan vench en l'altre dia, tornam -lo veer and when came.3SG on the;other day do;again.1PL =him see.INF e enviam -lo a pregar que.ns prestàs $\cdot \mathrm{c} \cdot \mathrm{mília}$ sous, and sent.1PL=him to beg-inf that=to; us lend.2SG.PRS.SBJV100,000 sous e él dix que sí faria ab que nós li ho and he said-3SG that si do.3PL.COND with that we to;him=it= asseguràssem.

ensured.1PL.PST.SBJV

'And, on the following day, we went back to see him, and sent someone to beg him that he would lend us 100,000 sous and he said that he would indeed do it, as long as we would provide a guarantee.'

$L d F$, fol. $74 \mathrm{r}, 1.15$

All three examples are found in non-veridical licensing environments. In (40), it is the direct question asked by the Aragonese men to Ramir II. In (41), it is the indirect question conveyed in the protasis that precedes the si do-support answer. Finally, in (42) the licensing context is the intentional verb pregar. Therefore, we can establish that the presence of sí in do-support answers is also licensed by non-veridical contexts, as it is the case with sí V-echo structures and sí in fully fledged clauses. Given these similarities, we presume that the underlying structure of sí V-echo and sí do-support is the same. ${ }^{11}$

\subsection{Sí in infinitival clauses}

Furthermore, in $L d C J C$, we find two cases of sí co-occurring with the negative adverb no:

11 As kindly pointed out by one of the reviewers of this article, the expression síno $\mathrm{fa}$ 'yes it does/does not', is still in use as an emphatic means to answer to yes/no questions in Valencia, Majorca and Ibiza varieties, according to the Diccionari Català Valencià Balear entry of sí. 
a. Fo demanada si sap que.1 dit Vidal

was.3SG asked if knows that; the aforementioned Vidal

degués altre deute al dit en Bernat.

owed.3SG.SBJV other debt to; the aforementioned sir Bernat

Dix que no.s sap.

said.3SG that not=3.SG.REFL knows

Fo demanada sobre totes altres entergacions e circunstàncies

was asked about all other details and circumstances

del feyt, e dix sí no saber àl re.

Of;the matter and said.3SG indeed not know.INF other thing

'She was asked if she knew whether Vidal had any other debts towards the aforementioned Sir Bernat. She said that she did not know. She was asked about all the other details and circumstances around the matter, and she said that she did indeed know nothing else.'

LdCJC, book 6, 145

b. $\quad\left[\mathrm{CP} \ldots\right.$ [FocP $\left[\right.$ SpecFocP Síi $\left[\mathrm{F}^{\prime},[\mathrm{Foc}]\left[\mathrm{PolP}\left[\mathrm{Pol}{ }^{\prime}\left[\mathrm{Pol} \mathrm{Pol}+\mathrm{t}_{\mathrm{i}}\right]\right]\left[\mathrm{TP}\left[\Sigma \mathrm{P}\left[\Sigma,\left[\Sigma\right.\right.\right.\right.\right.\right.$ no $\left[\mathrm{T}^{\prime}\right.$ [T ] [vP saber àl re ]]]]]]]]]]

In (43), sí is found within an infinitival complement clause that acts as the direct object of the verb dix 'she said'. Assuming Puntain's (1999) and Sitaridou's (2002) analysis for personal infinitives as declarative complements in Old Spanish, we consider that (43) is a learned construction borrowed from Latin's AccusativeInfinitive construction. Interestingly, the infinitive is projected with a left periphery where sí can be hosted. The co-occurrence of sí and no within the same clause is not a problem for our analysis, since the former encodes relative polarity features in the left periphery and the latter absolute polarity features within the inflectional domain, with scope over the predicate and not over the whole proposition. The co-occurrence of sí marking emphatic positive polarity and no simply encoding negation is also possible in Modern Catalan, backing up the idea of the existence of two polarity related constructions.

With this in mind, the analysis required to account for the distribution of si in Old Catalan has to explain the differences between those cases in which si appears in fully fledged clauses, without VP ellipsis and with clitics intervening between sí and the verb, and sí V-echo and sí do-support structures. But before proposing an analysis that may account for both these contexts, a last use of sí in Old Catalan needs to be considered: sí as a positive sentential proform competing with $\grave{o}$.

\subsection{Sí as a positive sentential proform}

As has been illustrated in examples (16) and (17) above, Old Catalan, like Old Occitan, had grammaticalised the Latin neuter demonstrative HOC into the positive sentential proform $\grave{o c}$. However, data from the $L d C J C$ shows that by the $13^{\text {th }}$ century, sí had already been grammaticalised as a positive sentential proform which displayed a distribution very similar to that of sí in Modern Catalan: it appears as the answer to yes/no questions in reported indirect speech, and it can either occur on its own, asserting the positive value of the proposition introduced in the interrogative clause, or followed by the complementiser que, conveying emphatic positive polarity. The positive sentential proform usage is illustrated in examples (44)-(46): 
(44) E nós dixem: 'Batayla?' e dix ell: and we said.1PL battle and said.3SG he Sí, seyor, que certament hi devem ésser est matí. yes sir that indeed there must.1PL be.INF this morning 'And we said: 'Battle?', and he said: 'Yes, sir, because we have to be there this same morning'.'

$L d F$, fol. $100 \mathrm{v}, 1.16^{12}$

(45) $\mathrm{E}$ fo demanat P(ere) Alcoy si vol ren dir and was.3SG asked Pere Alcoy whether wants anything say.INF a la dita dels testimonis. Dix que sí e (...) to the declaration of; the witnesses said.3SG that yes and 'And it was asked to Pere Alcoy if he wanted to say anything about the witnesses' intervention. He said that yes and (...)'

LdCJC, Book 2, 42

(46) E fo demanat Paschal de Xivert si ho podia and was.3SG asked Paschal de Xivert whether it=could.3SG provar. Dix que sí e vanà provar $(\ldots)$ prove.INF said.3SG that yes and boasted.3SG prove.INF 'And Pasqual de Xivert was asked if he could prove it. He said that yes and presented as proof (...)'

LdCJC, Book 3, 57

The negative sentential proform no 'no' displays exactly the same distribution as sí: it appears as an answer standing for a whole proposition in answers to yes/no questions in indirect speech.

(47) Fo demanat Abdumelich si él vené al was.3SG asked Abdumelich whether he sold.3SG to; the dit J(ohan) la arrova d'oli per III sous e IIII diners. Dix said Joan the quarter of;oil for 3 sous and 4 cents said.3SG que no. that no 'It was asked to Abdumelich whether he had sold to the aforementioned Joan the quarter of oil for 4 sous and 3 cents. He said that he did not.' LdCJC, Book 2, 90

12 In a previous version of this article I suggested that (44) could potentially be understood as a case of sí taking a complement clause as a complement, headed by que. However, the intervention of the vocative seyor 'lord' between sí and que should not be possible if that were the case. Therefore, I take (44) to be the only instance of $s i$ as a positive sentential proform found in $L d F$, and que to be introducing an embedded adverbial clause, probably causative, or alternatively, quotative. 
We assume that the structure of positive and negative answers via sentential proforms in Old Catalan is parallel to the structure proposed by Holmberg (2015), which we reproduce here, applied to example (45):

(48) a. Question: [CP do [IP you [ \pm Pol] want to say anything else ]]

Paraphrase: 'What is the value of $[ \pm \mathrm{Pol}]$ such that "you $[ \pm \mathrm{Pol}]$ want to say something else" is true?

b. Affirmative answer: 'sí' + PolP elision

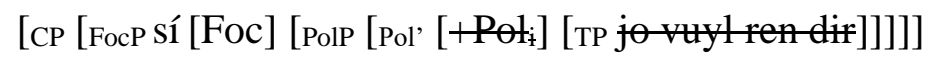

Both in the case of affirmative and negative answers, the TP is elided since it is identical to that of the question, and thus, the polarity particle acts as a sentential proform and stands in place of a full declarative clause. Based on this evidence, we conclude that like $o x$, sí was already a positive sentential proform by the $13^{\text {th }}$ century.

\subsection{An analysis}

We agree with Batllori and Hernanz (2013) and Rodríguez-Molina (2014) in assuming that si's V-echo and do-support answers are amongst the contexts where sí could have been reanalysed, but they are not the only ones. As it has been extensively shown in this section, in the $13^{\text {th }}$ century, si frequently appears in narrative texts in fully fledged clauses as an EPPA. Therefore, we propose that it is in main clauses within the scope of non-veridical operators that sí was reanalysed as an EPPA and lent itself to then be grammaticalised as a positive sentential proform in the context of answers to yes/no questions.

On the view of the data presented, $13^{\text {th }}$ century Old Catalan displays a complex picture in regard to the syntax of sí. It can appear in three different types of structures that display significant differences in relation to syntactic structure, as it is summarised in Table 3:

\begin{tabular}{|l|l|l|}
\hline & Sí in fully fledged clauses & $\begin{array}{l}\text { Sí V-echo } \\
\text { Sí do-support }\end{array}$ \\
\hline $\begin{array}{l}\text { Non-veridical licensing } \\
\text { context }\end{array}$ & + & + \\
\hline Sí-cl - V & + & - \\
\hline VP ellipsis & - & + \\
\hline
\end{tabular}

Table 3 -Features of the constructions with sí

For sí in fully fledged clauses, we have proposed an analysis in (34), which we reproduce here for the reader's convenience:

$$
\begin{aligned}
& \text { Sí in Old Catalan main clauses } \\
& \text { [Force [Top [SpecFocP Sí } \hat{i}_{\mathrm{i}}\left[\mathrm{FocP} \mathrm{V}_{\mathrm{j}}\left[\mathrm{PolP} \mathrm{t}_{\mathrm{i}}\left[\mathrm{Pol},+\mathrm{t}_{\mathrm{j}}\left[\mathrm{TP} \mathrm{t}_{\mathrm{j}}\left[\mathrm{VP} \mathrm{t}_{\mathrm{j}} \ldots \text { ] ] }\right]\right]\right]\right]\right.
\end{aligned}
$$

This analysis accounts for sí's EPPA status, it assumes that sí is base-generated in PolP, and that it moves to SpecFocP to receive emphatic reading. At that point, similarly to wh-operators, with which it is mutually exclusive, it attracts the verb to $\mathrm{Pol}^{\circ}$, to value it positively, and then to Foc ${ }^{\circ}$, to provide it with emphatic value. This explains why subjects cannot intervene between si and the verb, while they can occur in TopP when left dislocated, as we have seen in (19), and the possibility of having 
VP based postverbal subjects, as in (21). However, this analysis cannot account for the VP ellipsis involved in the sí v-echo and sí do-support structures.

$S i ́$ v-echo and sí do-support structures require a mechanism that would allow for VP ellipsis and that can explain the absence of clitic pronouns appearing between si and the verb.

According to Martins (2013:100), VP ellipsis is only possible in Modern European Portuguese when there is V-to- $\Sigma \mathrm{P}$ movement, and there is a discourse antecedent of the verb available. Modern European Portuguese has a structure, which Martins refers to as emphatic verb reduplication, which is used as a mechanism to encode positive polarity in a polarity reversal context. She dissects these structures as follows:

$$
\begin{aligned}
& \text { Ele não comprou o carro, pois não? } \\
& \text { he not bought the car, POIS NEG } \\
& \text { 'John didn't buy the car, did he?' }
\end{aligned}
$$

b. Comprou comprou. bought bought 'Yes, he DID.'

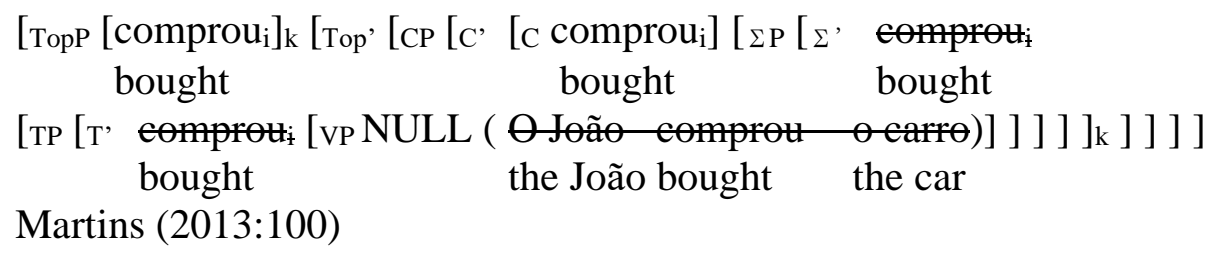

The derivation of (51) is the following: the verb moves to $\Sigma$ and subsequently to $\mathrm{C}$. The higher copy of the verb is morphologically reanalysed, and it becomes a $\mathrm{C}^{\mathrm{o}}$, thus avoiding a clash with the Linear Correspondence Axiom. Afterwards, there is remnant movement of $\Sigma \mathrm{P}$ to SpecTopP after VP ellipsis has already taken place, licensed by the movement of the raising of the verb to $\Sigma \mathrm{P}$ (recall that $\Sigma \mathrm{P}$ is a projection related to polarity located below $\mathrm{CP}$ and above TP).

Similarly, Rodríguez Molina (2014) links the availability of V-echo and dosupport structures in Old Spanish by linking it to verb movement and polarity. Nevertheless, in his proposal, he argues that in Old Spanish the verb raised to PolP in the left periphery in unmarked assertive declarative clauses, as shown in (52). In negative clauses, the verb would remain in TP, and no would be spelled out in $\Sigma$ P, blocking verb movement to PolP.

(52) a. Unmarked positive declarative clauses in Old Spanish

[ForceP ... [PolP $\mathrm{V}_{\mathrm{i}}$ [FinP... [TP [ $\left.\left.\left.\left.\left.\mathrm{T}, \mathrm{t}_{\mathrm{i}}\left[\mathrm{VP} \mathrm{t}_{\mathrm{i}}\right]\right]\right]\right]\right]\right]$

b. Unmarked negative declarative clauses in Old Spanish [ForceP ... [FocP [PolP [FinP [TP [ $\left[\Sigma \mathrm{P}\left[\Sigma,[\Sigma\right.\right.$ no $\left.\left.\left.\left.\left.]\left[\mathrm{T},\left[\mathrm{T} \mathrm{V}_{\mathrm{i}}\right]\left[\mathrm{vp}_{\mathrm{i}}\right]\right]\right]\right]\right]\right]\right]$ Adapted from Rodríguez Molina (2014:890)

He considers that in Old Spanish, sí had not yet been grammaticalised as an EPPA. Therefore, it was base-generated in VP, and then, it underwent move to the left periphery to receive an emphatic reading. By virtue of the verb then moving to FocP, 
the complement of this projection could be elided and yield sí V-eco and sí do-support constructions. These constructions would be derived as in (53):

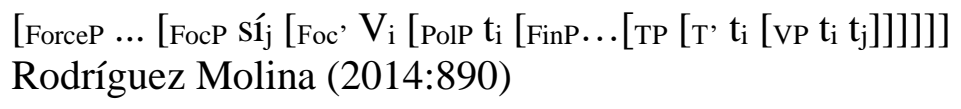

Old Catalan did not have verb movement to the left periphery in unmarked main clauses (Pujol i Campeny 2018, 2019). Therefore, these analyses are not readily applicable to the Old Catalan data unless we assume that in these structures, there is independent movement of the verb from TP-to- $\Sigma \mathrm{P} / \mathrm{PolP}$-FocP, where the complement of FocP could be elided, preventing the spell out of lower copies of the verb and the apparition of lower VP material.

This being the case, it can be postulated that Old Catalan had two competing strategies for the expression of emphatic positive polarity, an archaising one on its way out akin to those of Old Spanish with V-to- $\Sigma \mathrm{P} / \mathrm{PolP}$, and an emerging structure, akin to that found in Modern Spanish. The key difference between both structures is sí in fully fledged clauses, requires the lexical item sí to have already been reanalysed as an EPPA that triggers the movement of the verb to $\mathrm{Foc}^{\circ}$, while to produce si v-echo and sí do-support structures, there needs to be independent verb movement to $\mathrm{Pol}^{\circ}$. This situation can be accounted for if we postulate the existence of two grammars for the encoding of emphatic positive polarity in Old Catalan: one strongly connected to Verum Focus, with sí base-generated in PolP and verb movement to the left periphery to value PolP, and one in which the verb independently raises to the left periphery without the need of another constituent moving to it, and the complement of the projection to which it is moved is elided.

Therefore, we can conclude that Old Catalan was the first Old Romance language to grammaticalise sí as an EPPA. We can also establish that the existence of $\mathrm{V}$-echo and do-support strategies suggests that at some point, the language did have V-to- $\Sigma$ P/PolP, a type of movement that by the $13^{\text {th }}$ century it was only preserved in archaising $\mathrm{V}$-echo and do support constructions, that failing to be perceived as markers of emphatic positive polarity on their own, always co-occurred with sí.

Furthermore, as shown in section 4.6, Old Catalan had gone a step further and had grammaticalised sí as a positive sentential proform, competing with òc:

\section{[CP [FocP Sí [Foc] [PolP [Pol’ [+Pol $\left.{ }_{i}\right]$ [TP ]]]]]}

This analysis strengthens the hypothesis that Old Catalan does not fit in the V2 generalisations that have been proposed for Old Romance word order (Benincà 1984; Vanelli, Renzi, and Benincà 1986; Roberts 1993; Benincà 2006, 2004; Wolfe 2015a, among others), and that it can provide us with very valuable data regarding the evolution of the Romance languages.

In the case of the grammaticalisation of sí into a positive sentential proform, we agree with Batllori and Hernanz (2013) and Rodríguez Molina (2014) that is reanalysed as a sentential proform in answers to direct or indirect yes/no questions, where it was first used as an EPPA within the scope of a non-veridical operator. Therefore, we propose that the grammaticalisation path of si from a manner adverb (an XP) to a positive sentential proform (a head) is the following: 


\begin{tabular}{|c|c|c|c|}
\hline & {$[\mathrm{CP} \ldots[$ FocP $\ldots[$ [PolP $\ldots[$ [TP . } & & \\
\hline b. & $\begin{array}{c}{\left[\mathrm{CP} \ldots \text { [FocP SÍ }_{\mathrm{i}}[\mathrm{PolP} \ldots[\mathrm{TP}\right.} \\
\text { thus }\end{array}$ & {$[\mathrm{VP}$} & \\
\hline & $\begin{array}{l}{\left[\mathrm{CP} \ldots \text { [FocP SÍ }_{\mathrm{i}}\left[\mathrm{PolP}+\mathrm{t}_{\mathrm{i}}[\mathrm{TP}\right.\right.} \\
\text { indeed }\end{array}$ & {$[\mathrm{VP}$} & \\
\hline & $\begin{array}{l}{\left[\mathrm{CP} \ldots \text { [FocP SÍ }_{\mathrm{i}}\left[\mathrm{PolP}+\mathrm{t}_{\mathrm{i}}[\mathrm{TP}\right.\right.} \\
\text { yes }\end{array}$ & {$[\mathrm{vP}$} & \\
\hline
\end{tabular}

SIC starts off as a manner adverb, a maximal category, based-generated within VP (Cinque 1999). This adverb often underwent fronting to convey Verum focus and gain scope over the predicate. That is, the action described in the proposition was done in one specific way and no other. It was in this context that si was then reanalysed as an EPPA: instead of being base-generated in VP, like manner adverbs, it became associated to emphatically asserting a proposition and base-generated in PolP where it values relative polarity features. Once base-generated in PolP, sí undergoes categorical change, as it becomes a head and a sentential proform, like its negative counterpart no. Through its appearance in the answers of yes/no questions, which are identical to their question, it becomes reanalysed as a positive sentential proform, which, like $\grave{o c}$ is basegenerated in $\mathrm{Pol}^{\circ}$, moves to the $\mathrm{Foc}^{\circ}$ to convey emphasis, and allows for the elision of $\mathrm{TP}$, which is identical to the question's.

These findings set the date of grammaticalisation of sí as a positive sentential proform back to $13^{\text {th }}$ century. Batllori and Hernanz (2008:ft. 19) suggest that $\grave{c} c$ was the positive sentential proform in use in Old Catalan until the $14^{\text {th }}$ century. While $o c$ is indeed attested until the $15^{\text {th }}$ century in CICA, the data presented here shows that

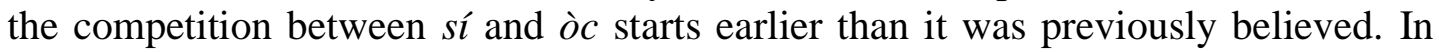
$L d C J C, 65$ cases of sí used as a positive sentential proform are attested, while $\grave{o c}$ is only found in two occasions. The reverse is true of $L d F$ and $C B D$ : in these two texts, $\grave{o} c$ is the most frequent positive sentential proform, while sí is only attested once in $L d F$ and never in $C B D$, in spite of already being grammaticalised when these texts were written, as we have shown. The distribution of these two forms, which were already in competition, is determined by register, as shown extensively in Pujol i Campeny (in press).

In $L d C J C$, stretches of reported speech uttered by the people involved in the

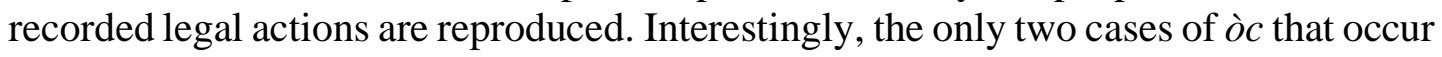
in this text are attributed to the same person, Ramon Escrivan, and belong to book 1, written in 1269. Torró (2009) suggests that Ramon Escrivan might have been in charge of the Cocentaina's notary offices, where the legal records were produced. The language of Ramon Escrivan, a literate man holding one of the most important positions in town and whose election had to be validated by the King himself, must have differed from the language of his contemporary laymen, who resorted to the notary to put into writing petty conflicts with neighbours and mundane legal acts such as the signature of loan contracts. One of the differences seems to be the choice of positive sentential proform. While Ramon Escrivan chose to use $\grave{c} c$, the same form used in chronicles narrating the feats of Aragonese kings and in poetry, a genre written exclusively in Occitan until the $15^{\text {th }}$ century, his illiterate contemporaries preferred to use sí. More data and a more thorough analysis of the distribution of sí and òc diachronically is required to obtain a clear picture of the diastratic and diamesic 
variables that determined it, but the data presented here points towards the importance of understanding and investigating register and diastratic variation to better understand the evolution of Catalan syntax.

\section{Summary of findings}

In this article, we have demonstrated that by the $13^{\text {th }}$ century, Old Catalan sí had already been grammaticalised as a PPI: it was used to express emphatic positive polarity in non-veridical contexts and it had already been grammaticalised as a positive sentential proform that could answer yes/no questions. It has also been shown that strategies associated with the expression of emphatic positive polarity in the Old Romance languages, such as V-echo and do-support, could only take place in Old Catalan in the presence of sí (there are no cases of sí-less V-echo or do-support attested in the texts consulted). The appearance of sí in these structures points towards the coexistence of two constructions to express emphatic positive polarity in $13^{\text {th }}$ century Old Catalan: a more archaising one, allowing for the production of $\mathrm{V}$-echo and dosupport clauses, and a more innovative one, where sí had already been grammaticalised as an Emphatic Positive Polarity Item and as positive sentential proform, becoming necessary in V-echo and do-support answers. Furthermore, the

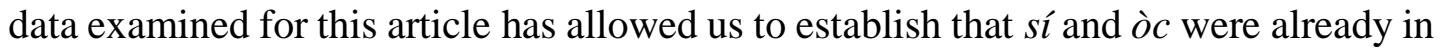
competition by the $13^{\text {th }}$ century, at least a century earlier than it was previously believed, and that their distribution responded to register and genre. This suggests that a better understanding of the interaction between syntax, register and genre can greatly broaden our knowledge of the syntax of the Old Romance language and its evolution.

\section{References}

Adams, Jim Noel. 1994. "Wackernagel's Law and the Position of Unstressed Personal Pronouns in Classical Latin." Transactions of the Philological Society 92: 10378.

Adams, Marianne. 1987. "From Old French to the Theory of Pro-Drop." Natural Language \& Linguistic Theory 5 (1): 1-32. http://www.jstor.org/stable/4047573.

Batllori, Montserrat, and Maria Lluïsa Hernanz. 2008. "Emphatic Polarity from Latin to Romance." Poster. The 10th Diachronic Generative Syntax Conference. New York. http://habilis.udg.edu/ info/Activitat_Docent_Recerca_Gestio/Montserrat_Ba tllori/BatlloriHernanzPosterDIGSXCornell.pdf.

Batllori, Montserrat, and Maria Lluïsa Hernanz. 2009. "Foco oracional y polaridad. Entorno a una asimetría entre el español y el catalán" Handout. VIII Congreso Internacional de Historia de la Lengua Española. Santiago de Compostela.

Batllori, Montserrat, and M. Lluïsa Hernanz. 2013. "Emphatic Polarity Particles in Spanish and Catalan." Lingua 128. Elsevier B.V.: 9-30. https://doi.org/10.1016/j.lingua.2012.11.010.

Batllori, Montserrat, and M. Lluïsa Hernanz. 2015. "Weak focus and polarity: Asymmetries between Spanish and Catalan." In Syntax over Time: Lexical, 
Morphological and Information Structural Interactions. Oxford: Oxford University Press: 280-298.

Benincà, Paola. 1984. "Un'ipotesi Sulla Sintassi Delle Lingue Romanze Medievali." Quaderni Patavini Di Linguistica, no. 4: 3-19.

- 2004. "The Left Periphery of Medieval Romance." Studi Linguistici e

Filologici Online 2: 243-297.

. 2006. "A Detailed Map of the Left Periphery of Medieval Romance." Edited by Rafaella Zanuttini, Héctor Campos, Elena Herburger, and Paul Portner. Crosslinguistic Research in Syntax and Semantics Negation Tense and Clausal Architecture 2. Washington : Georgetown University Press : 53-86. http://www.doaj.org/abstract?id=106082\& toc $=y$.

Benincà, Paola, and Cecilia Poletto. 2004a. "A Case of Do-Support in Romance." Natural Language \& Linguistic Theory 22 (1): 51-94.

- 2004b. "Topic, Focus, and V2." In The Structure of CP and IP, edited by Luigi Rizzi, 52-75. Oxford: Oxford University Press.

Biberauer, Theresa, and Ian Roberts. 2008. "Subjects, Tense and Verb Movement in Germanic and Romance." Cambridge Occasional Papers in Linguistics 3: 2443.

Clackson, James. 2007. Indo-European Linguistics: An Introduction. Cambridge: Cambridge University Press.

Danckaert, Lieven. 2014. "Quidem as a Marker of Emphatic Polarity." Transactions of the Philological Society 112 (1): 97-138. https://doi.org/10.1111/1467968X.12009.

Devine, A. M., and Laurance D. Stephens. 2006. Latin Word Order. 1st ed. Oxford: Oxford University Press.

Donaldson, Bryan. 2016. "Preverbal Subjects, Information Structure, and Object Clitic Position in Old Occitan." Journal of Linguistics 52 (01): 37-69. https://doi.org/10.1017/S0022226714000619.

Ernst, Thomas. 2009. "Speaker-Oriented Adverbs." Natural Language \& Linguistic Theory 27 (3): 497-544. https://doi.org/10.1007/sl.

Farkas, Donka F., and Kim B. Bruce. 2010. "On Reacting to Assertions and Polar Questions." Journal of Semantics 27 (1): 81-118. https://doi.org/10.1093/jos/ffp010.

Fleischman, Suzanne. 1991. "Discourse Pragmatics and the Grammar of Old French: A Functional Reinterpretation of Si and the Personal Pronouns." Romance Philology 44: 251-83.

Garrett, Jordan. 2013. "Which Que Is Which ?: A Squib on Reduplicative Que Complementizers in Iberian Spanish Embedded Clauses." Indiana University Linguistics Club Working Papers 13 (5): 1-9.

Giannakidou, Anastasia. 1998. Polarity Sensitivity as (Non)Veridical Dependency. Amsterdam: John Benjamins Publishing Company. . 1999. "Affective Dependencies." Linguistics and Philosohy 22: 367-421. 2001. "Varieties of Polarity Items and the (Non)Veridicality Hypothesis." In Perspectives on Negation and Polarity Items, edited by Jack Hoeksema, Hotze Rullman, Víctor Sánchez-Vanencia, and Ton van der Wouden. Amsterdam: John Benjamins Publishing Company.

. 2008. "Negative and Positive Polarity Items: Variation, Licensing, and Compositionality." In Semantics: An International Handbook of Natural 
Language Meaning, edited by Claudia Maienborn, Klaus von Heusinger, and Paul Portner. Berlin: Mouton de Gruyter.

Haegeman, Liliane. 2003. "Conditional Clauses: External and Internal Syntax." Mind \& Language 18 (4): 317-39. https://doi.org/10.1111/1468-0017.00230.

. 2009. "The Movement Analysis of Temporal Adverbial Clauses." English Language and Linguistics 13 (October 2009): 385. https://doi.org/10.1017/S1360674309990165. . 2010. "The Internal Syntax of Adverbial Clauses." Lingua 120: 628-48. https://doi.org/10.1016/j.lingua.2008.07.007.

Holmberg, Anders. 2001. "The Syntax of Yes and No in Finnish" 55 (2): 141-75. https://doi.org/10.1093/acprof:oso/9780198701859.001.0001.

. 2015. "Verb Second." In Syntax - Theory and Analysis : An International Handbook., edited by Tibor Kiss and Artemis Alexiadou, 342-83. Berlin, Boston: Mouton de Gruyter.

. 2016. The Syntax of Yes and No. Oxford: Oxford University Press. https://doi.org/10.1093/acprof:oso/9780198701859.001.0001.

Hooper, Paul J., and Sandra. A Thompshon. 1973. "On the Applicability of Root Transformations." Linguistic Inquiry 4: 465-97.

Krifka, Manfred. 2008. "Basic Notions of Information Structure." Acta Linguistica Hungarica. https://doi.org/10.1556/ALing.55.2008.3-4.2.

Laka, Miren Itziar. 1990. "Negation in Syntax: On the Nature of Functional Categories and Projections." Massachusetts Institute of Technology.

Ledgeway, Adam. 2007. "Old Neapolitan Word Order: Some Initial Observations." In Histories and Dictionaries of the Languages of Italy, edited by Anna Laura. Lepschy and Arturo. Tosi, 121-49. Longo: Ravenna.

—. 2008. "Satisfying V2 in Early Romance: Merge vs. Move." Journal of Linguistics 44 (02): 437-70. https://doi.org/10.1017/S0022226708005173.

Leonetti, Manuel, and Victoria Escandell Vidal. 2009. "Fronting and Verum-Focus in Romance." In Focus and Background in Romance Languages.

Marchello-Nizia, Christiane. 1985. Dire Le Vrai: L'adverbe "si" En Français Médiéval : Essai de Linguistique Historique. Genève: Droz.

Martins, Ana Maria. 2013. "Emphatic Polarity in European Portuguese and Beyond." $\begin{array}{lllll}\text { Lingua } & 128 . & \text { Elsevier } & \text { B.V.: }\end{array}$ https://doi.org/10.1016/j.lingua.2012.11.002.

Pérez Saldanya, Manuel and Martines, Josep. 2009. Corpus Informatitzat del Català Antic (CICA): http://lexicon.uab.cat/cica. 2009.

Poletto, Cecilia. 2005. "Sì and e as CP Expletives in Old Italian." In Grammaticalization and Parametric Variation, edited by Montserrat Batllori, Maria Luisa Hernanz, Carme Picallo, and Francesc Roca, 206-35. Oxford: Oxford University

Press. https://doi.org/10.1093/acprof:oso/9780199272129.003.0013. 2014. Word Order in Old Italian. Oxford: Oxford University Press.

Poletto, Cecilia, and Raffaella Zanuttini. 2013. "Emphasis as Reduplication: Evidence from Sì Che/No Che Sentences." Lingua 128. Elsevier B.V.: 124-41. https://doi.org/10.1016/j.lingua.2012.10.016.

Pountain, Christopher. 1998. "Learnèd syntax in the Romance languages: the Accusative and Infinitive construction with declarative verbs in Castilian". Transactions of the Philological Society, 96 (2): 152-201. 
Pujol i Campeny, Afra. 2019. "V1 Clauses in Old Catalan". In: Breitbarth, Anne, Miriam Bouzouita, Melissa Farasyn, Lieven Danckaert (Eds.), The Determinants of Diachronic Stability. Amsterdam: John Benjamins, pp. 157190.

2018. Word Order in Old Catalan. PhD Thesis. Department of Theoretical and Applied Linguistics, University of Cambridge.

. In press. "Sí and hoc in the history of Catalan: from the 13th to the 17th century". Revue Romane.

Quer, Josep. 2002. "Edging Quantifiers. On QP-Fronting in Western Romance". In Romance Languages and Linguistic Theory 2000 - Selected papers from 'Going Romance' 2000, Utrecht, 30 November-2 December, Edited by Claire Beyssade, Reineke Bok-Bennema, Frank Drijkoningen and Paola Monachesi. Amsterdam, Philadelphia: John Benjamins

Reenen, Pieter van, and Lene Schløsler. 2000. "The Pragmatic Functions of the Old French Particles Ainz, Apres, Donc, Lors, or, Puis, and Si." In Textual Parameters in Older Languages, edited by Susan C. Herring, Lene Schøsler, and Pieter van Reenen, 59-109. John Benjamins Publishing Company.

Riquer, Martín. 1964. Història de La Literatura Catalana. Barcelona: Ariel.

Rizzi, Luigi. 1997. "The Fine Structure of the Left Periphery." In Elements of Grammar, edited by L. Haegeman, 1997th ed., 281-337. Dordrecht, London: Kluwer Academic Publishers.

Roberts, Ian. 1993. Verbs and Diachronic Syntax. A Comparative History of English and French. Dordrecht: Kluwer Academic Publishers.

Roberts, Ian, and Anna Roussou. 2003. Syntactic Change: A Minimalist Approach to Grammaticalisation. Cambridge: Cambridge University Press.

Rodríguez Molina, Javier. 2014. "La Gramática Oculta de La Polaridad Positiva En Español Antiguo.” Revista de Filología Hispánica 30 (3): 861-915.

Salvesen, Christine Meklenborg. 2013. "Topics and the Left Periphery. A Comparison of Old French and Modern Germanic." In In Search of Universal Grammar : From Old Norse to Zoque, edited by Terje Lohndal, 131-72. Amsterdam; Philadelphia: John Benjamins Publishing Company.

Salvesen, Christine, and George Walkden. n.d. "Diagnosing Embedded V2 in Old English and Old French." In From Micro-Change to Macro-Change. Oxford: Oxford University Press.

Salvi, Giampaolo. 2002. "Il Problema di <si> e l'uso Riflessivo Di Essere." Verbum IV (2): 377-328.

Sitaridou, Ioanna. 2003. "On the Licensing of Null Subjects in Old French." Syntactic Structures and Morphological Information.

- 2009. "On the emergence of personal infinitives in the history of Spanish". Diachronica, 26 (1): 36-64.

—. 2019. "Word Order in Old Spanish: V2 or Not V2?" In The Determinants of Diachronic Stability, edited by Anne Breitbarth, Miriam Bouzouita, Melissa Farasyn, and Lieven Danckaert. Amsterdam: John Benjamins Publishing Company.

Spevak, Olga. 2012. "Les Enclitics Enim et Autem Dans La Diachronie Du Latin.” In Les Evolutions Du Latin, edited by Alain Christol and Olga Spevak, 335-52. Paris: Assotiation Kubaba.

Steiner, Britanny Devan Jelm. 2014. "The Evolution of Information Structure and 
Verb Secpnd in The History of French." Indiana University.

Torró, Jordi (Ed.). 2009. Llibre de la Cort de Justícia de Cocentaina (1268-1290). Fonts Històriques Valencianes 43a. València: Publicacions Universitat de València.

. 2011. Llibre de la Cort de Justícia de Cocentaina (1294-1295). Fonts Històriques Valencianes 43b. València: Publicacions Universitat de València.

Vance, Barbara. 1993. "Verb-First Declaratives Introduced by et and the Position of pro in Old and Middle French." Lingua 89 (2-3): 281-314. https://doi.org/10.1016/0024-3841(93)90055-2.

- 1997. Syntactic Change in Medieval French : Verb-Second and Null Subjects. Dordrecht, London: Kluwer Academic Publishers.

Vance, Barbara, Bryan Donaldson, and B. Devan Steiner. 2010. "V2 Loss in Old French and Old Occitan: The Role of Fronted Clauses." In Romance Linguistics 2009 - Selected Papers from the 39th Linguistic Symposium on Romance Languages (LSRL), Tucson, Arizona, March 2009, edited by Sonia Colina, Antxon Olarrea, and Ana Maria Carvalho, 301-20. Amsterdam; Philadelphia: John Benjamins Publishing Company.

Vanelli, Laura, Lorenzo Renzi, and Paola Benincà. 1986. "Quaderni Patavini Di Linguistica." Quaderni Patavini Di Linguistica 5: 49-66.

Villa-García, Julio. 2015. The Syntax of Multiple-Que Sentences in Spanish: Along the Left Periphery. Amsterdam; Philadelphia: John Benjamins Publishing Company.

Wolfe, Sam. 2015. Microvariation in Medieval Romance Syntax: A Comparative Study. PhD Thesis. University of Cambridge.

Wolfe, Sam. 2018. "Probing the syntax of a problematic particle: Old French 'si' revisited." Transactions of the Philological Society, 116 (3): 332-362. 